\title{
Genetic Variability in Agro-morphological and Quality Traits of Mediterranean Durum Wheat Landraces
}

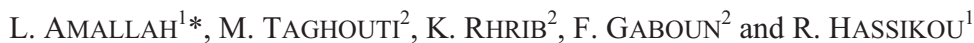 \\ ${ }^{1}$ Faculty of Sciences of Rabat, Avenue Ibn Battouta B.P. 1014 RP, Rabat, Morocco \\ ${ }^{2}$ National Institute of Agronomical Research, Avenue Mohamed Belarbi Alaoui B.P. 6356, Rabat, Morocco
}

(Received 14 December 2013; Accepted 15 May 2014;

Communicated by F. Békés)

\begin{abstract}
Durum wheat landraces are still cultivated to take advantage of their excellent grain and straw quality, adaptation to abiotic stresses, and extremely wide variety of uses. The safeguarding and rehabilitation of genetic inheritance requires genetic characterization and evaluation. In this study, forty durum wheat landraces originating from Mediterranean countries were evaluated according to agro-morphological and technological properties. We show that the germplasm was highly variable. The mean yellow pigment and protein content was higher in landraces $(15.58 \% ; 7.32 \mathrm{ppm})$ than in the Moroccan cultivars used as controls $(14.6 \% ; 5.48$ $\mathrm{ppm})$. In addition, principal component analysis identified five groups showing variable agronomic and qualitative characteristics that might be useful in the rational design of breeding programs.
\end{abstract}

Keywords: Triticum turgidum L. var. durum, landraces, genetic diversity, agro-morphological traits, quality traits

\section{Introduction}

Wheat grain is a staple food that contains numerous compounds beneficial to nutrition and health (Kimball et al. 2001; Zhao et al. 2009), particularly proteins, carbohydrates, and carotenoids. In total, $16 \%$ and $26 \%$ of the total dietary calories come from wheat in developing and developed countries, respectively (Ortiz et al. 2008). As wellbeing of nutritional value, these components also constitute a criterion for the assessment of semolina quality.

Historically, durum wheat (Triticum turgidum ssp. durum) was first domesticated over 12,000 years ago in the Middle East, with its cultivation and use subsequently spreading globally during the Neolithic Revolution (Charmet 2011). Commercially speaking, it is an important tetraploid wheat species and the major grain source of semolina for production of pasta, couscous and bulgur that originated and diversified in the Mediterranean Basin (Mac Key 2005). This region, in spite of its climate, accounts for $60 \%$ of global wheat production and represents the greatest source of genetic diversity in durum wheat germplasm,

* Corresponding author; E-mail: 1.amallah@hotmail.com 
as indicated by the high levels of polymorphism present in local landraces (Moragues et al. 2006, 2007; Royo et al. 2010).

Landraces are a mixture of traditional crop varieties developed by farmers through years of natural and human selection, and which are adapted to local environmental conditions and management practices (Ganeva et al. 2010). Although their yields are often low (Ehdaie et al. 1988; Blum et al. 1989), Mediterranean landraces have been found to be well adapted and possess traits that are lacking in modern cultivars (Moragues et al. 2006).

The global demand for grain is expected to have grown by $40 \%$ by 2020 , compared to levels in the latter half of the 1990s (Rosegrant 1997), in line with increasing food diversity and market demand (Zhang et al. 2004; Wang et al. 2005). There is therefore renewed interest in wheat landraces and primitive cultivars as an important source of genetic variation (Brush 1995), mainly because the trend towards greater uniformity has narrowed the genetic basis of modern wheat cultivars and increased their vulnerability to biotic and abiotic stresses (Masood et al. 2005). In view of this, there is a need to develop new genotypes with improved nutritional qualities combined with high yields (Iftikhar et al. 2012). Landraces, as a reservoir of underexploited genetic diversity (De Vita et al. 2007), can therefore contribute to the development of germplasm pools (Srivastava et al. 1988).

Grain protein concentration, gluten strength, and yellow pigment content are the most important quality attributes for durum breeding, and have driven the focus of breeders' activities in recent years (Blanco et al. 2011). Of these, protein content is the most important trait in wheat production and the most important factor determining the end-use quality, such as in pasta-making (Zhao et al. 2010), in which high nutritional value (Blanco et al. 2011) and strong gluten are desirable (Troccoli et al. 2000). The swelling capacity of gluten proteins in durum wheat affects the rate of sedimentation of a meal suspension in sodium dodecyl sulfate (SDS) medium, with higher gluten strength giving rise to slower sedimentation rate and higher sedimentation volume (Kumar et al. 2013). Strong gluten confers greater firmness and stability to pasta after cooking, whereas pasta made with weak gluten semolina tends to deteriorate rapidly and become soft with overcooking (Payne 1987). More recently, pasta color has become important as an aesthetic factor that influences consumer choice (Feillet et al. 2000; De Vita et al. 2007) and is largely determined by the accumulation of carotenoids in the endosperm. Carotenoids are also excellent antioxidants, and have been shown to reduce oxidative damage to biological membranes by scavenging peroxyradicals (Bast et al. 1996), which also contributes to the increased nutritional value of pasta products (Troccoli et al. 2000).

In this study, we used a variety of assays to explore the variability in landrace genotypes of durum wheat from nine different Mediterranean countries, including Morocco, in order to assess the agro-morphological traits and factors that affect the quality of durum wheat semolina. 


\section{Materials and Methods}

\section{Plant material}

A set of forty accessions of durum wheat (Triticum turgidum L. var. durum), of which 24 landraces originated from Morocco, were collected by the National Institute of Agronomical Research. Sixteen durum landraces originated from six southern and eastern Mediterranean countries were provided by the Gene Bank of the International Center for Agricultural Research in the Dry Areas (ICARDA). In addition, five Moroccan cultivars, 'Karim, 'Tomouh', 'Marzak', 'Oued Zenati', and 'Isly' were included as controls; the details of these taxa are presented in Table $\mathrm{S} 1 *$.

\section{Agro-morphological evaluation}

Agro-morphological assessment was conducted in trials at Allal Tazi $\left(34^{\circ} 31^{\prime} \mathrm{N}, 6^{\circ} 19^{\prime} \mathrm{W}\right.$; INRA's research station) using an augmented block design. Each entry was sown in two rows $2.5 \mathrm{~m}$ long and spaced at $0.3 \mathrm{~m}$. Standard agronomic management of soil preparation, fertilization, and weeding were applied, and the fertilizer used was 19-38-0 (N-P-K) complex applied at $150 \mathrm{~kg} / \mathrm{ha}$, and amino nitrate $(33.5 \% \mathrm{~N})$ applied at $100 \mathrm{~kg} / \mathrm{ha}$.

During the study, four quantitative agro-morphological traits, namely days to heading, days to maturity, plant height and 1000-kernel weight, were recorded using Bioversity International Durum Wheat Descriptors.

\section{Quality traits assessment}

The quality parameters evaluated for each genotype were gluten strength determined by the SDS (Sodium Dodecyl Sulfate) Sedimentation test following a standard method (American Association for Cereal Chemistry (AACC) 1984), with the Marzak cultivar used as check. Yellow pigments concentration particularly carotenoids content were assayed by AACC 14-50 modified method (Santra et al. 2003). Color was evaluated by measuring brightness $\left(\mathrm{L}^{*}\right)$ and yellow index $\left(\mathrm{b}^{*}\right)$ using reflectance colorimeter, the Chroma Meter CR-400 (Konica Minolta) (D’Egidio et al. 1990), with the Tomouh cultivar used as control for the yellow pigment tests. Proteins content was determined by using the standard Kjeldahl method (AACC 1976), with the Oued Zenati cultivar used as control. Test weight was determined by using an Aqua-TR (Tripette and Renaud Chopin).

\section{Statistical analysis}

Differences between groups were compared by analysis of variance (ANOVA) and with the Tukey post-hoc test; $p<0.05$ was considered statistically significant. In addition, principal components analysis (PCA) and Pearson correlation coefficients (r-values) determine relationships and correlations between various characteristics. All statistical analyses were performed using SAS software version 9.1 (SAS Institute Inc, Cary, NC, 1997).

* Further details about the Electronic Supplementary Material (ESM) can be found at the end of the article. 


\section{Results}

The analysis of genetic variability is based on both of the four agro-morphological traits and five quality traits of 40 durum wheat genotypes. Local durum accessions were variable for the most of traits evaluated (Table S2). With respect to agronomic traits, there was a large variation in heading time between landraces, ranging from $100 \pm 7.65$ to $122 \pm 7.65$ days (mean $110.32 \pm 7.65$ days), and from $100 \pm 0.96$ to $102 \pm 0.96$ days for cultivars (mean $101.25 \pm 0.96$ days). Physiological maturity ranged from $160 \pm 2.36$ to $167 \pm 2.36$ days for landraces (mean $164.55 \pm 2.36$ days), and for cultivars it ranged from $160 \pm 0.5$ (for Marzak) to $161 \pm 0.5$ days (for Karim, Tomouh, and Isly; mean $160.75 \pm 0.5$ days). Some of the accessions (PL3, PL11, PL15, PL22, PL24, PL36, PL39, and PL44) were early maturing. The evaluation of plant height suggested a decreasing trend from old to modern cultivars, from $154 \pm 13.25 \mathrm{~cm}$ for landraces to $109 \pm 7.42 \mathrm{~cm}$ for the Tomouh cultivar. The 1000-kernel weight ranged from $20.83 \pm 5.14$ to $45.17 \pm 5.14$ (mean $32.52 \pm$ $5.14 \mathrm{~g}$ ) for landrace genotypes, and between $32.02 \pm 4.2$ and $41.25 \pm 4.2 \mathrm{~g}$ for cultivars (mean $37.99 \pm 4.2 \mathrm{~g}$ ). The test weight showed similar results, ranging from $64.64 \pm 5.86$ to $87.73 \pm 5.86 \mathrm{~kg} \mathrm{hL}^{-1}$ (mean $79.22 \pm 5.86 \mathrm{~kg} \mathrm{hL}^{-1}$ ) for landraces and from $81.26 \pm 4.18$ to $90.69 \pm 4.18 \mathrm{~kg} \mathrm{hL}^{-1}$ for cultivars (Isly the highest; mean $86.32 \pm 4.18 \mathrm{~kg} \mathrm{hL}^{-1}$ ).

There were significant differences in all the quality traits studied; a clear trend was evident for the yellow pigment parameters ( $b$, L, beta-carotene concentration, or yellow pigment content) from landrace genotypes compared to cultivars. The landrace genotypes exhibited significantly higher yellow pigment concentrations compared to cultivar controls (Table S3). In fact, of the genotypes evaluated (Tables S2 and S3), the yellow pigment content values of landraces were higher than those observed for the Tomouh cultivar used as control ( $9.79 \pm 1.17 \mathrm{ppm}$ and $8.36 \pm 2.28 \mathrm{ppm}$, respectively); furthermore, the lowest value was $5.26 \pm 1.17 \mathrm{ppm}$, whereas in cultivars it was $3.53 \pm 2.28 \mathrm{ppm}$ (Isly). Similar results were observed for yellow index $\mathrm{b}$ compared to the Tomouh cultivar control $(\mathrm{b}=$ $21.54 \pm 2.21)$. By contrast, the same accessions expressed brown index $L$ values relatively lower than observed with Tomouh $(\mathrm{L}=89.28 \pm 1.88)$. Protein concentrations decreased from landraces to cultivars, the mean value dropping from $15.58 \pm 2.12 \%$ in landraces to about $14.59 \pm 0.6 \%$ in cultivars, compared to $16.09 \pm 0.6 \%$ in the Oued Zenati cultivar control (Table S1). With respect to SDS sedimentation volume, the mean value was approximately the same in landraces $(44.53 \pm 7.87 \mathrm{ml})$ and cultivars $(45.09 \pm 16.39 \mathrm{ml})$. SDS volume was significantly lower in landrace genotypes $(18.9 \pm 7.87 \mathrm{ml})$ compared to the lowest cultivar value (Karim; $28.3 \pm 16.39 \mathrm{ml})$. The highest SDS volume was observed in the Marzak cultivar $(63.3 \pm 16.39 \mathrm{ml})$, compared to $58.2 \pm 7.87 \mathrm{ml}$ in the landrace genotypes.

PCA was used to visualize and compare durum wheat trait relationships and their role in genotype characterization. PCA explained $75 \%$ of the total variation, which is a good approximation of the total variation of the standardized data (Fig. S1). Test weight (PS), protein content (TP), and yellow pigment parameters (L, b and YP) explained component $\mathrm{PC} 1$ and $60 \%$ of the variation. $15 \%$ of the variation was explained by PC2: days to heading (JE), days to maturity (JM), and gluten strength (SDS) had the greatest effect. Expecting 
the gluten strength, all the other traits evaluated (thousand-kernel weight, plant height, days to maturity, days to heading) have relatively a long vectors, suggesting that there was relatively large variation among accessions especially the yellow pigment; where the mean value of yellow pigment index seems to be the highest at landraces in comparison to modern cultivars (Isly, Karim, Tomouh and Marzak). The Pearson correlation coefficient (r) values (Table S4) show that days to heading was positively and very significantly correlated with days to maturity $(\mathrm{r}=0.887)$, but the correlations between 1000-kernel weight and phenological characters were very weak $(r=0.005 ; r=-0.004)$. Plant height correlated positively with days to heading $(r=0.427)$ and days to maturity $(r=0.447)$. Test weight correlated negatively with days to maturity and days to heading $(r=-0.317$ and $r=$ -0.279 , respectively) but positively and very significantly with 1000 -kernel weight $(\mathrm{r}=$ $0.611)$. A strong and significant correlation was observed between yellow pigment concentration and the yellow index $b(r=0.656)$.

\section{Discussion}

Variance analysis (Table S3) revealed significant variability between the 40 accessions for all traits, consistent with previous studies of variability in durum wheat landraces (Taghouti et al. 2006; Zarkti et al. 2010). With respect to agronomic traits, a large variation in heading time was present within the landraces. Conversely, a progressive reduction in the vegetative phase was observed in cultivars, due to the breeding improvements made in these modern accessions. The early heading time was strongly correlated with maturity days, since the length of the life cycle was only marginally reduced (Fig. S1 and Table S3). The accessions PL3, PL11, PL15, PL22, PL24, PL36, PL39, and PL44, which were generally early durum wheat landraces, can therefore be used in breeding programs to develop early maturing varieties. The evaluation of plant height indicated that landraces were relatively taller than the improved cultivars. This is a typical feature of landraces, which excel in their capacity to support panicle growth by large stem reserve mobilization (Ayed et al. 2010). In fact, short plant height confers a better capacity to tolerate dryness (Ben Abdallah and Ben Salem 1993), which might be explained by greater glucose storage ability in the stems during the period preceding anthesis (Oury et al. 1995). The 1000-kernel weight, one of the most important yield components considered in the selection criteria for developing high-yield wheat genotypes (Iftikhar et al. 2012), shows a clear increase over time from landraces to modern cultivars, indicating that breeders have been successful in improving the yield of this crop, in agreement with some (Tesfaye et al. 1991; Masood et al. 2005; Koksal 2009), but not all, authors (Siddique et al. 1989; Slafer and Andrade 1989; Slafer and Miralles 1993) all reported that modern cultivars have a lower grain weight than older cultivars. This difference may be due to variations in the genotypes studied or the prevailing environmental conditions.

With respect to the association between various traits and the 1000-kernel weight, we can conclude the following: days to heading was positively and significantly correlated with plant height, while there was a negative association between phonologic traits (days to heading and days to maturity) and the 1000-grain weight. In addition, ANOVA and 
PCA analysis showed that the landraces that were, on average, later in days to heading and days to maturity were taller than the cultivars, but had lower values for 1000-kernel weight, clearly indicating the effectiveness of early maturing genotypes for obtaining higher grain yields. These results help us to appreciate the selective pressure imposed by breeders on phonology and plant height in order to select cultivars well adapted to semi-arid conditions, where early maturity is better suited to drought. This finding represents a benchmark for future durum breeding activities and is consistent with the published literature (Belay et al. 1993; Ramzan et al. 1994; Khan et al. 2010). These parameters can be used as direct criteria for improving durum wheat yields.

With respect to grain quality, there has been historical interest in test weight due to its relationship with semolina yield (Irvine 1964; Matsuo and Dexter 1980). In this study, there was a significant positive correlation between 1000-kernel weight and test weight (0.45), in contrast to the results of others (Matsuo and Dexter 1980; Troccoli and Di Fonzo 1999). Although these two parameters affect the same characteristic, they seem to behave differently with respect to milling yield. With respect to protein content, our results show that modern cultivars frequently have lower grain protein concentrations than landraces, consistent with previous findings (Austin et al. 1980; Slafer et al. 1990; Calderini et al. 1995; Ortiz-Monasterio et al. 1997). The increase in yield component traits is likely to be accompanied by a decrease in protein content, which is a well-known phenomenon (Lawlor 2002; Triboli and Triboi-Blondel 2002; Martre et al. 2003). Bogard et al. (2008) suggest that grain protein content and 1000-kernel weight are related to genetic incompatibility (linkage, pleiotropy), partitioning efficiency, and competition for photosynthetic energy between nitrogen and carbon-1, 2, 3.

SDS sedimentation volume had short vectors in PCA analysis, suggesting that the variability between accessions and cultivar controls was small; this is probably due to polygenic control of gluten strength and a possible environmental effect on their expression, as suggested by previous genetic studies (Kumar et al. 2013). Both the landraces and cultivars exhibited strong gluten strength on average, implying lower softening and compressibility values compared to recent studies, in which SDS-volumes range from 20.5 to $38.0 \mathrm{~mL}$ (Sayaslan et al. 2012) and from 17.3 to $28.7 \mathrm{~mL}$ (Sakin et al. 2011). The yellow amber color of durum wheat semolina and pasta remains of commercial value; our results show that yellow pigment concentration is higher in landrace accessions than in modern cultivars ( $9.79 \pm 1.17)$; however, it is reported that the yellow pigment contents of durum wheat fluctuates between 4 and $8 \mathrm{ppm}$ (Troccoli et al. 2000). Since additive gene effects largely control this trait with high heritability (Elouafi et al. 2001), it will be useful to exploit landrace richness in breeding programs aimed at improving the nutritional value of durum and its end-products. A strong significant correlation was also observed between the yellow pigment concentration and the yellow index $\mathrm{b}(0.656)$, as noted previously (Blanco et al. 2011). The yellow index is a useful, fast, and safe method for screening yellow pigments in large-scale wheat breeding programs.

Overall, results shows that durum wheat landraces explored from Mediterranean countries harbor a broad range of genetic variation reflect the fact that local durum wheat has been selected and used for centuries for different products. In the present study, a number 
of promising accessions have been identified that harbour specific traits, especially protein content and yellow pigment, which may have potential value in durum wheat breeding programs that aim to combine high carotenoid concentration with high nutritional protein content and maintain yield. This has the potential to improve the nutritional, health, and commercial quality of durum wheat.

\section{Acknowledgements}

The authors would like to thank Mr. Mustapha KAMAR (INRA, Rabat) for technical assistance, and the Nextgenediting Global Initiative (www.nextgenediting.com) for editorial help.

\section{References}

AACC. 1976. Approved Method No. 56-70 of the American Association of Cereal Chemistry American Association of Cereal Chemistry. St. Paul, MN, USA.

AACC. 1984. Approved Methods 7th edition of the American Association of Cereal Chemistry American Association of Cereal Chemistry. St. Paul, MN, USA.

Austin, R.B., Bingham, J., Blackwell, R.D., Evans, L.T., Ford, M.A., Morgan, C.L., Taylor, M. 1980. Genetic improvements in winter wheat yields since 1900 and associated physiological changes. J. Agric. Sci. 94: 675-689.

Ayed, S., Karmous, C., Trifa, Y., Slama-Ayed, O., Slim-Amara, H. 2010. Phenotypic diversity of Tunisian durum wheat landraces. Afr. Crop Sci. J. 18:35-42.

Bast, A., Van der Plas, R.M., Van der Berg, H., Haenen, G.R. 1996. $\beta$-Carotene as antioxidant. Eur. J. Clin. Nut. 50:S54-S56.

Belay, G., Tesemma, T., Mitiku, D. 1993. Variability and correlation studies in durum wheat in Alem-Tena, Ethiopia. Rachis News Letter 12:38-40.

Ben Abdallah, N., Ben Salem, M. 1993. Paramètres morpho physiologiques de sélection pour la résistance à la sécheresse (Morpho-physiological parameters selection for drought resistance). In: INRA tolérance à la sécheresse des céréales en zone méditerranéenne. I. Diversité génétique et amélioration variétale (Drought Tolerance of Cereals in Mediterranean Areas. I. Genetic Diversity and Plant Breeding). INRA. Paris, France, pp. 253-264. (in French)

Blanco, A., Colasuonno, P., Gadaleta, A., Mangini, G., Schiavulli, A., Sincone, Digesù, A.M., De Vita, P., Mastranpelo, A.M., Cattivelli, L. 2011. Quantitative trait loci for yellow pigment concentration and individual carotenoid compounds in durum wheat. J. Cereal Sc. 54:255-264.

Blum, A., Golan, G., Mayer, J., Sinmena, B., Shpiler, L., Burra, J. 1989. The drought response of landraces of wheat from the northern Negev desert in Israel. Euphytica 43:87-96.

Bogard, M., Moreau, D., Allard, V., Martre, P., Le Gouis, J. 2008. Genetic analysis of grain protein deviation in wheat. Proc. $11^{\text {th }}$ International Wheat Genetics Symposium, Brisbane, Qld, Australia, pp. 473-475.

Brush, S.B. 1995. In situ conservation of landraces in centers of crop diversity. Crop Sci. 35:346-354.

Calderini, D.F., Torres-Leon, S., Slafer, G.A. 1995. Consequences of wheat breeding on nitrogen and phosphorus yield, grain nitrogen and phosphorus concentration and associated traits. Ann. Bot. 76:315-322.

Charmet, G. 2011. Wheat domestication. I. Lessons for the future, C.R. Biol. 334:212-220.

D'Egidio, M.G., Mariani, B.M., Novaro, P. 1990. Chemical and technological variables and their relationships: A predictive equation for pasta cooking quality. Cereal Chem. 67:275-281.

De Vita, P., Destri Nicosia, O.L., Nigro, F., Platani, C., Riefolo, C., Di Fonzo, N., Cattivelli, L. 2007. Breeding progress in morpho-physiological, agronomical and qualitative traits of durum wheat cultivars released in Italy during the $20^{\text {th }}$ century. Eur. J. Agron. 26:39-53.

Ehdaie, B., Waines, J.G., Hall, A.E. 1988. Differential responses of landrace and improved spring wheat genotypes to stress environments. Crop Sci. 28:838-842. 
Elouafi, I., Nachit, M.M., Martin, L.M. 2001. Identification of a microsatellite on chromosome 7B showing a strong linkage with yellow pigment in durum wheat (Triticum turgidum L. var. durum). Hereditas 135:255-261.

Feillet, P., Autran, J.C., Icard, C. 2000. Pasta brownness: An assessment. J. Cereal Sci. 32:215-233.

Ganeva, G., Korzum, V., Landjeva, S., Popova, Z. 2010. Genetic diversity assessment of Bulgarian durum wheat (Triticum durum Desf.) landraces and modern cultivars using microsatellites markers. Gen. Res. Crop Evol. 57:273-285.

Iftikhar, R., Khaliq, I., Kashif, M., Ahmad, M.A., Ullah, S. 2012. Study of morphological traits affecting grain yield in wheat (Triticum aestivum L.) under field stress condition. Middle-East J. Sci. Res. 11:19-23.

Irvine, G.N. 1964. Über die Mahleigenschaften von kanadischen Durumweizen (About the milling properties of Canadian durum wheat). Getreide Mehl 14:37-39. (in German)

Khan, A.J., Azam, F., Ali, A. 2010. Relationship of morphological traits and grain yield in recombinant inbred wheat lines grown under drought conditions. Pak. J. Bot. 42:259-267.

Kimball, B.A., Morris, C.F., Pinter, Jr. P.J., Wall, G.W., Hunsaker, D.J., Adamsen, F.J., LaMorte, R.L., Leavitt, S.W., Thompson, T.L., Matthias, A.D., Brooks, T.J. 2001. Elevated $\mathrm{CO}_{2}$, drought and soil nitrogen effects on wheat grain quality. New Phytol. 150:295-303.

Koksal, Y. 2009. Path coefficient analysis of some yield components in durum wheat (Triticum durum Desf.) Pak. J. Bot. 41:745-751.

Kumar, A., Elias, E.M., Ghavami, F., Xu, X., Jain, S., Manthey, F.A., Mergoum, M., Alamri, M. S., Kianian, P.M.A., Kianian, S.F. 2013. A major QTL for gluten strength in durum wheat (Triticum turgidum L. var. durum). J. Cereal Sci. 5:21-29.

Lawlor, D.W. 2002. Carbon and nitrogen assimilation in relation to yield: Mechanisms are the key to understanding production systems. J. Exp. Bot. 53:773-787.

Mac Key, J. 2005. Wheat, its concept, evolution and taxonomy. In: Royo, C., Nachit, M.M., Di Fonzo, N., Araus, J.L., Pfeiffer, W.H., Slafer, G.A. (eds), Durum Wheat Breeding. I. Current Approaches and Future Strategies. Food Products Press, New York, USA, pp. 3-61.

Martre, P., Porter, J.R., Jamieson, P.D., Triboi, E. 2003. Modelling grain nitrogen accumulation and protein composition to understand the sink/source regulations of nitrogen remobilization for wheat. Plant. Physiol. 133:1959-1967.

Masood, S., Javaid, A., Rabbani, A., Anwar, R. 2005. Phenotypic diversity and trait association in bread wheat (Triticum aestivum L.) landraces from Baluchistan, Pakistan. Pak. J. Bot. 37:949-957.

Matsuo, R.R., Dexter, J.E. 1980. Relationship between some durum wheat characteristics and semolina milling properties. Can. J. Plant Sci. 60:49-53.

Moragues, M., Zarco-Hermández, J., Moralejo, M. A., Royo, C. 2006. Genetic diversity of glutenin protein subunits composition in durum wheat landraces [Triticum turgidum ssp. Turgidum convar. Durum (Desf.) Mackey] from the Mediterranean Basin. Gen. Res. Crop Evol. 53:993-1002.

Moragues, M., Moralejo, M. A., Sorrells, M. E., Royo, C. 2007. Dispersal of durum wheat landraces across the Mediterranean basin assessed by AFLPs and microsatellites. Gen. Res. Crop Evol. 54:1133-1144.

Ortiz, R., Braun, H.J., Crossa, J., Crouch, J.H., Davenport, G., Dixon, J., Dreisigacker, S., Duveiller, E., He, Z., Huerta, J., Joshi, A.K., Kishii, M., Kosina, P., Manes, Y., Mezzalama, M., Morgounov, A., Murakami, J., Nicol, J., Ferrara, G.O., Ortiz-Monasterio, J., Payne, T.S., Peña, R.J., Reynolds, M.P., Sayre, K.D., Sharma, R.C., Singh, R.P., Wang, J., Warburton, M., Wu, H., Iwanaga, H.M. 2008. Wheat genetic resources enhancement by the International Maize and Wheat Improvement Centre (CIMMYT). Gen. Res. Crop Evol. 55:1095-1140.

Ortiz-Monasterio, R.J.I., Sayre, K.D., Rajaram, S., McMahon, M. 1997. Genetic progress in wheat yield and nitrogen use efficiency under four N rates. Crop Sci. 37:898-904.

Oury, F.X., Triboi, E., Berard, P., Ollier, J.L., Roussout, M. 1995. Etude des flux de carbone et d'azote chez des blés hybrides et leurs parents pendant la période de remplissage des grains (Carbon and nitrogen flows in hybrid wheats and their parents during grain filling). Agronomie 15:193-204. (in French)

Payne, P.I. 1987. Genetics of wheat storage proteins and the effect of allelic variation on bread-making quality. Ann. Rev. Plant Physiol. 38:141-153.

Ramzan, M., Chowdhry, M.A., Khaliq, I. 1994. Correlation between wheat grain yield and its components. J. Agr. Res. 32:222-227.

Rosegrant, A.L. 1997. Wheat demand in future. Oxford Econ. Pap. 28:102-117.

Cereal Research Communications 43, 2015 
Royo, C., Maccaferri, M., Álvaro, F., Moragues, M., Sanguineti, M.C., Tuberosa, R., Maalouf, F., García del Moral, L.F., Demontis, A., Sayar, R., Nachit, M., Nserallah, N., Villegas, D. 2010. Understanding the relationships between genetic and phenotypic structures of a collection of elite durum wheat accessions. Field Crop Res. 119:91-105.

Sakin, M.A., Sayaslan, A., Duzdemir, O., Yuksel, F. 2011. Quality characteristics of registered cultivars and advanced lines of durum wheats grown in different ecological regions of Turkey. Can. J. Plant Sci. 91:261-271.

Santra, M., Rao, V.S., Tamhankar, S.A. 2003. Modification of AACC procedure for measuring $\beta$-carotene in early generation durum wheat. Am. Assoc. of Cereal Chemists, Inc. Cereal Chem. 80:130-131.

Sayaslan, A., Koyuncu, M., Yildirim, A., Eserkaya Gulec, T., Ateş Sonmezoğlu, O., Kandemir, N. 2012. Some quality characteristics of selected durum wheat (Triticum durum) landraces. Turk. J. Agric. For. 36:749-756.

Siddique, K.H.M., Kirby, E.J.M., Perry, M.W. 1989. Ear to stem ratio in old and modern wheats; relationship with improvement in number of grains per ear and yield. Field Crop Res. 21:59-78.

Slafer, G.A., Andrade, F.H. 1989. Genetic improvement in bread wheat (Triticum aestivum) yield in Argentina. Field Crop Res. 21:289-296.

Slafer, G.A., Andrade, F.H., Satorre, E.H. 1990. Genetic-improvement effects on pre-anthesis physiological attributes related to grain yield. Field Crop Res. 23:255-263.

Slafer, G.A., Miralles, D.J. 1993. Fruiting efficiency in three wheat (Triticum aestivum) cultivars released at different eras. Number of grains per spike and grain weight. J. Agr. Crop Sci. 170:251-260.

Sourour, A., Chahine, K., Youssef, T., Olfa, S.A., Hajer, S.A. 2010. Phenotypic diversity of Tunisian durum wheat landraces. Afr. Crop Sc. J. 18:35-42.

Srivastava, J.P., Damania, A.B., Pecetti, L. 1988. Landraces, primitive forms and wild progenitors of macaroni wheat, Triticum durum. I. their use in dry land agriculture. Proc. Seventh International Wheat Genetics Symposium. Cambridge, UK, pp. 153-158.

Taghouti, M., Gaboun, F., Nsarellah, N., Rhrib, K., Nachit, M.M., Saïdi, S., Boujnah, M., Maataoui, F. 2006. Analyse de la diversité génétique de populations locales de blé dur et potentialités d'utilisation en amélioration génétique (Analysis of genetic diversity of durum wheat landraces and potential use in genetic improvement). Alawamia 3:120. (in French)

Tesfaye, T., Getachew, B., Worede, M. 1991. Morphological diversity in tetraploid wheat landrace populations from the central highlands of Ethiopia. Hereditas 114:171-176.

Triboli, E., Triboi-Blondel, A.M. 2002. Productivity and grain or seed composition. I. A new approach to an old problem - invited paper. Eur. J. Agr. 16:163-186.

Troccoli, A., Di Fonzo, N. 1999. Relationship between kernel size features and test weight in Triticum durum. Cereal Chem. 76:45-49.

Troccoli, A., Borrelli, G.M., De Vita, P., Fares, C., Di Fonzo, N. 2000. Durum wheat quality. I. A multidisciplinary concept. J. Cereal Sci. 32:99-113.

Wang, H., Li, Z.J., Ma, Y.M., Zhao, C., Ning, T.Y., Jiao, N.Y. 2005. Current status and research advances on quality regionalization in the high quality wheat. J. Triticeae Crops 25:112-114.

Zarkti, H., Ouabbou, H., Hilali, A., Udupa, S.M. 2010. Detection of genetic diversity in Moroccan durum wheat accessions using agro-morphological traits and microsatellite markers. Afr. J. Agr. Res. 5:1837-1844.

Zhang, Y., He, Z.H., Ye, G.Y., Zhang, A.M., Ginkel, M.V. 2004. Effect of environment and genotype on bread-making quality of spring-sown spring wheat cultivars in China. Euphytica 139:75-83.

Zhao, C.X., He, M.R., Wang, Z.L., Wang, Y.F., Lin, Q. 2009. Effects of different water availability at post-anthesis stage on grain nutrition and quality in strong-gluten winter wheat. C.R. Biol. 332:759-764.

Zhao, L., Zhang, K.P., Liu, B., Deng, Z.Y., Qu, H.L., Tian, J.C. 2010. A comparison of grain protein content QTLs and flour protein content QTLs across environments in cultivated wheat. Euphytica 174:325-335. 


\section{Electronic Supplementary Material (ESM)}

Electronic Supplementary Material (ESM) associated with this article can be found at the website of CRC at http://www.akademiai.com/content/120427/

Electronic Supplementary Table S1. Accession code, origin IG, and origin of 40 durum wheat accessions
used in this study

Electronic Supplementary Table S2. Means and standard deviations of the 40 landrace genotypes and four agro-morphological and quality traits analyzed

Electronic Supplementary Table S3. Variance analysis for 40 landrace genotypes and four Moroccan cultivars used as controls for ten agro-morphological and quality traits

Electronic Supplementary Table S4. Pearson correlation coefficients (r)

between the different traits analyzed

Electronic Supplementary Figure S1. A durum wheat genotype by trait biplot based on 40 genotypes, four agro-morphological traits, and six quality characteristics. DE: days to heading, DM: days to maturity, H: plant height, PS: test weight, PMG: thousand-kernel weight, TP: protein content, YP: yellow pigment, L: brightness, b: yellow index, and SDS: SDS volume 